\title{
Chemotaxonomical and Palynological Studies on Nine Acacia Species Occurring in Sudan
}

\author{
Sakina Yagi ${ }^{1}$, Palmina Khristova ${ }^{2} \&$ Sami Ahmed Khalid ${ }^{3}$ \\ ${ }^{1}$ Botany Department, Faculty of Science, University of Khartoum, Khartoum, Sudan \\ ${ }^{2}$ Department of Forest Products and Industries, Faculty of Forestry, University of Khartoum, Khartoum, Sudan \\ 3 Department of Pharmacognosy, Faculty of Pharmacy, University of Khartoum, Khartoum, Sudan \\ Correspondence: Sakina Yagi, Botany Department, Faculty of Science, University of Khartoum, Khartoum, \\ Sudan. Tel: 249-915-030-004. E-mail: sakinayagi@yahoo.com
}

Received: March 2, 2012 Accepted: April 29, 2012 Online Published: August 10, 2012

doi:10.5539/jps.v1n2p61 URL: http://dx.doi.org/10.5539/jps.v1n2p61

\begin{abstract}
The present study was carried out on the chemotaxonomy and palynology of nine Acacia species occurring in Sudan. It included a preliminary phytochemical screening of the flowers extracts using thin layer chromatography (TLC) followed by isolation of the major compounds from A. nilotica flowers. Palynological results showed that the studied species, except for $A$. laeta, can be divided into two types; Type 1 pollen characterized by spinescent stipules and Type 2 pollen typified by non-spinescent stipules. A. laeta, in addition to all characters of Type 2 pollen, has polyads with 18-20 monads, a fact supporting its hybrid origin. TLC of extracts revealed the presence of phenolic substances with selective reactivity towards phenolic detectingreagents. TLC comparison of the isolated compounds with extracts from studied species revealed that gallic acid and its methyl ester were only persistent in Acacia species exhibiting spinescent stipules. Thus, suggesting their use as good chemotaxonomic markers.
\end{abstract}

Keywords: Acacia, flower compounds, taxonomic markers, gallic acid and its methyl ester, Acacia laeta

\section{Introduction}

The genus Acacia Miller currently includes about 1300 species and form the second-most species-rich genus in the family Leguminosae (Mabberley, 1997; Maslin, 2001). Acacia is widespread with a number of species in Africa, the Americas, Asia and Australia. Two third of its species are indigenous to Australia which makes Acacia the largest genus of vascular plants in the region (Maslin, 2001). The contribution of morphological, anatomical, ontogenetic and some phytochemical characters has been useful for the classification of the genus Acacia (Bentham, 1842, 1862, 1875; Vassal, 1972, 1981; Evans et al., 1977, 1993; Guinet \& Vassal, 1978; Pedley, 1986; Guinet, 1990; Dube et al., 2001; Bouchenak-Khelladi et al., 2010). In spite of this, there is still some controversy regarding the infrageneric taxonomy.

Acacia species (31 species) predominate in Sudan and are of high importance not only because of the gum produced by some of them but also for their medicinal and economical importance. They represent about one third of the African species (Elamin, 1972). The taxonomy of the different species is still not quite clear and several classifications have been proposed. Many botanists had published work related to Sudan Acacia (Crowfoot, 1929; Brown \& Massey, 1929; Andrews, 1952; Harison \& Jackson, 1958; Elamin, 1972; El Tinay et al., 1979). However, most of the published taxonomical work focused mainly and/or solely on the inflorescence character and classified them into spicate and capitate groups. Elamin (1972) provided the latest and more comprehensive taxonomical account on Sudan Acacia. He rejected the traditional classification which was based on inflorescence type and instead, he used palynology and anatomy in relation to vegetative characters, especially those derived from stipules. He proposed the division of Sudan Acacia into four subgeneric groups:

Group I: Stipules spinescent. Spines at nodes usually white straight and having a vascular system. Inflorescence globose heads, flowers white-cream, yellow, orange. Pollen grains in polyads (16-celled). $2 n=26,52,100$. Trees and shrubs.

Group II: Stipules non-spinescent. Prickles at nodes in pairs usually dark brown and having no vascular system. Inflorescence cylindrical spikes, pink or white-cream. Pollen grains in polyads (16-celled). $2 n=26$. Trees and 
shrubs.

Group III: Stipules non-spinenescent. Prickles scattered on internodes and rachis usually dark brown and having no vascular system. Inflorescence spikes and globose heads, flowers white-cream. Pollen grains in polyads (16celled) smaller in size than in Group II. $2 n=26$. All members of this group are climbers.

Group IV: Stipules spinescent, spines at nodes usually white straight and having a vascular system. Inflorescence cylindrical spikes, flowers white-cream. Pollen grains in polyads (28-32) -celled). $2 \mathrm{n}=26$. This Group is typified by only one species; A. albida Del. (Now is transferred to the genus Faidherbia; F. albida (Del.) A. Chev)

The classification of plants by lumping taxa according to morphological similarities is probably the oldest and most widely-used of all the approaches (Quinlan, 1993). However many approaches evolved over time towards the taxonomy of plants. As a result of the limited adequacy of traditional morphological taxonomy, where morphological and anatomical classifications prove complicated in certain instances, other sources of information are sought after. Chemosystematic data are usually valuable in the precise classification within the genera, complementing the other methods for reliable taxonomic classification (Stuessy, 2009). The present study is part of an attempt to subject Sudan Acacia to palynological and chemotaxonomical investigation to have a better understanding about the taxonomy of this genus in the light of the recent evidence.

\section{Materials and Methods}

\subsection{Plant Materials}

Authenticated flower specimens were collected from nine Acacia species (A. ehrenbergiana Hayne; A. laeta R. Br. ex Benth.; A. nilotica (L.) Willd. ex Del. ssp nilotica Brenan; Acacia nilotica (L.) Delile subsp. tomentosa (Benth.) Brenan; A. mellifera (Vahl) Benth.; A. senegal (L.) Willd.; A. seyal var. seyal Brenana; A. sieberana DC and $A$. tortilis (Forsk.) subsp. raddiana (Savi) Brennan growing wild in Khartoum. The botanical vouchers collected were taxonomically identified by late Prof. H.M. Elamin and deposited at Soba Forestry Research Centre Herbarium.

\subsection{Phytochemistry}

\subsubsection{General Experimental Procedures}

Thin layer chromatography (TLC) was performed on pre-coated silica gel plates (DC-Alufolien 60 F254, Merck) and preparative TLC (PTLC) plates were home prepared using silica gel H (Merck) powder. Column chromatography (CC) was carried out on polyamide (MN-polyamide SC6 polycaprolactam) and Sephadex LH-20 (Merck) columns. Spots were located by using $2 \% \mathrm{FeCl}_{3} / \mathrm{MeOH}$ and $5 \% \mathrm{AlCl}_{3} / \mathrm{EtOH}$ spraying reagents which are indicative for the presence of phenolics. NMR spectra were performed with a Bruker AM-400 instrument operating at a proton frequency of $400.13 \mathrm{MHz}$. The electron-impact $(70 \mathrm{eV})$ mass spectra were recorded on Varian $\mathrm{CH}-4$ and $\mathrm{CH}-7$ instruments.

\subsubsection{Extraction}

Flowers (20 g) were air dried at shade and coarsely powdered. The flowers of each species were extracted with aqueous methanol $(70 \%)$ in a Soxhlet apparatus for $24 \mathrm{hrs}$. The extracts were filtered and the methanol (MeOH) was evaporated under reduced pressure. The aqueous extracts were fractionated by partition with petroleum ether (PE) and ethyl acetate (EtOAc) successively. The EtOAc extracts were then dried using anhydrous sodium sulphate and evaporated to dryness under reduced pressure. For large scale extraction, the air- dried powdered flowers of A. nilotica ssp tomentosa $(1 \mathrm{~kg})$ were extracted with same above mentioned procedure.

\subsubsection{Preliminary Screening}

The EtOAc extracts of different flowers were subjected to preliminary screening on TLC using the ascending method. Chromatoplates were developed on solvent system: Toluene: EtOAc: Formic acid (5:4:1) (1), visualized under $\mathrm{UV}$ and sprayed with $\mathrm{FeCl}_{3} / \mathrm{MeOH}$ and $\mathrm{AlCl}_{3} / \mathrm{EtOH}$ spraying reagents.

\subsubsection{Isolation of Pure Compounds}

The EtOAc (95 g) extract was chromatographed on a polyamide column eluted with water/MeOH mixtures. A total number of 60 fractions $(75 \mathrm{~mL}$ each) were collected and finally 8 fractions were obtained on combining the eluates according to their chromatographic similarity behaviour on TLC. Fraction 2 (4 g) was applied to Sephadex LH-20 column using MeOH as eluent to obtain compounds 1 (250 mg) and 2 (300 mg). Fraction 5 (840 mg) was applied to PTLC using PE: EtOAc (8:2) as solvent system to obtain compounds 3 (22 mg) and 4 (97 mg). 


\subsection{Palynology}

Pollen samples were prepared by using the acetolysed technique as described by Erdman (1969). Anthers of flowers were placed in centrifuge tubes, moistured with $5 \mathrm{~mL}$ of glacial acetic acid and crushed with a glass rod. The tubes were immediately inverted and left to drain for about $2 \mathrm{hr}$ at room temperature. The pollens were then mounted with glycerine jelly on slides and sealed with colourless nail polish. The prepared slides were examined using a light microscope with an oil immersion objectives (X 100 magnification), dimensions measured and photographs were taken.

\section{Results}

\subsection{Screening of the EtOAc Extracts of Acacia Species}

Phytochemical screening of the EtOAc extracts of all studied Acacia species on TLC showed that $A$. ehrenbergiana, A. nilotica, A. seyal, A. sieberana and A. tortilis reacted positively to $\mathrm{FeCl}_{3}$ reagent. All species gave violet-coloured dominant spots. In addition, A. nilotica revealed a grey-coloured spot. Moreover, $A$. tortilis, A. sieberana, A. mellifera, A. laeta and A. senegal responded positively to the treatment with $\mathrm{AlCl}_{3}$ reagent when detected under UV light $(254 \mathrm{~nm})$. All of them exhibited yellow-coloured spots on TLC plates (Figure 1).

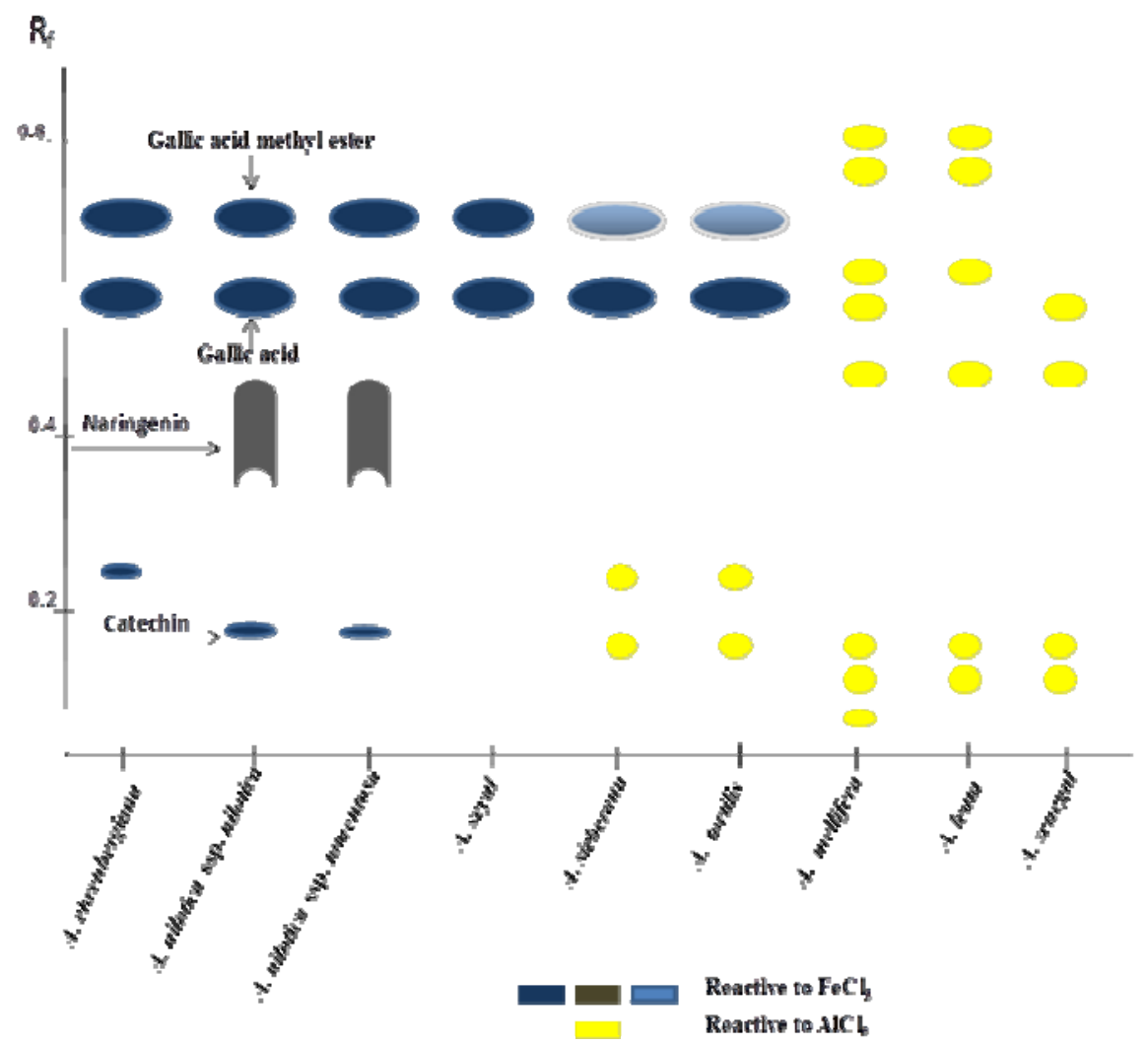

Figure 1. Thin layer chromatography of the ethyl acetate extracts from the flowers of Acacia species. Adsorbent: silica get; Solvent system: toluene: ethyl acetate: formic acid (5:4:1);

Spray reagents: $\mathrm{FeCl}_{3} / \mathrm{MeOH}$ and $\mathrm{AlCl}_{3} / \mathrm{EtOH}$

\subsection{Characterization of Isolated Compounds from A. nilotica ssp. Tomentosa}

\subsubsection{Compound 1 (gallic acid methyl ester)}

Compound $1(250 \mathrm{mg})$ was obtained as brownish powder. $\mathrm{R}_{\mathrm{f}}$ value 0.68 in solvent system (1), gave violet spot with $\mathrm{FeCl}_{3}$ reagent. The ${ }^{1} \mathrm{HNMR}$ spectrum $\left(400 \mathrm{MHz}, \mathrm{CD}_{3} \mathrm{OD}\right)$ was simple, showing only two peaks at $\delta 3.78(3$ $\mathrm{H}, \mathrm{OCH} 3)$ and $7.04(2 \mathrm{H}, \mathrm{H}-2$ and $\mathrm{H}-6)$. The high resolution mass spectrum of compound 1 showed an $\mathrm{E}^{+}$peak at $184\left(\mathrm{M}^{+}\right)$suggesting the molecular formula $\mathrm{C}_{8} \mathrm{H}_{8} \mathrm{O}_{5}$. On the basis of this spectroscopic evidences and data reported in the literature (Khalid et al., 1988) compound 1 was identified as gallic acid methyl ester (Figure 2). 
<smiles>O=C(O)c1cc(O)c(O)c(O)c1</smiles>

$$
\begin{array}{ll} 
& \text { R } \\
\text { Gallic acid } & \text { H } \\
\text { Gallic acid methyl ester } & \mathrm{CH}_{3}
\end{array}
$$<smiles>[R8]c1cc([C@@H]2Oc3cc(O)cc(O)c3C([B])C2[R6])ccc1O</smiles>

Catechin Naringenin

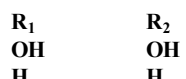

$\mathbf{H}$

\section{$\mathbf{R}_{\mathbf{3}}$ \\ H}

Figure 2. Structural formulae of the isolated compounds from the ethyl acetate extract of Acacia nilotica ssp tomentosa flower

\subsubsection{Compound 2 (gallic acid)}

Compound $2(300 \mathrm{mg})$ was obtained as greyish powder. $\mathrm{R}_{\mathrm{f}}$ value 0.59 in solvent system (1), gave violet spot with $\mathrm{FeCl}_{3}$ reagent. The ${ }^{1} \mathrm{HNMR}$ spectrum $\left(400 \mathrm{MHz}, \mathrm{CD}_{3} \mathrm{OD}\right.$ ) was very simple, showing only a single aromatic singlet at $\delta 7.04$ (2H, H-2 and H-6). The high resolution mass spectrum of compound 2 showed an $\mathrm{E}^{+}$peak at $170\left(\mathrm{M}^{+}\right)$suggesting the molecular formula $\mathrm{C}_{7} \mathrm{H}_{6} \mathrm{O}_{5}$. On the basis of this spectroscopic evidences and comparison with authentic sample compound 2 was identified as gallic acid (Figure 2).

\subsubsection{Compound 3 (naringenin)}

Compound 3 (22 mg) was obtained as light yellow-coloured powder. $R_{f}$ value of 0.40 on solvent system (1) and gave dark gery colour after spraying with $\mathrm{FeCl}_{3}$ reagent. The ${ }^{1} \mathrm{HNMR}$ spectrum $\left(400 \mathrm{MHz}, \mathrm{C}_{2} \mathrm{D}_{6} \mathrm{O}\right)$ exhibited AAXX system centered at $\delta 7.15$ and $7.64\left(\mathrm{H}^{\prime} 2^{\prime}, 3^{\prime}, 5^{\prime}\right.$ and $\left.6^{\prime}\right)$. An ABX system was observed at $\delta 2.97$ (dd, J= 3 and $\left.17 \mathrm{~Hz}, \mathrm{H}-3^{\text {trans }}\right)$ and $3.42\left(\mathrm{dd}, \mathrm{J}=13\right.$ and $\left.17 \mathrm{~Hz}, \mathrm{H}-3^{\text {cis }}\right)$. The remaining signals centered at $\delta 6.20((\mathrm{~d}, \mathrm{~J}=2 \mathrm{~Hz}$, $\mathrm{H}-6), 6.21(\mathrm{~d}, \mathrm{~J}=2 \mathrm{~Hz}, \mathrm{H}-8)$ and $12.43(\mathrm{~s}, 5-\mathrm{OH})$. The high resolution mass spectrum of compound 3 showed an $\mathrm{E}^{+}$peak at $273\left(\mathrm{M}^{+}+\mathrm{H}\right)$ suggesting the molecular formula $\mathrm{C}_{15} \mathrm{H}_{12} \mathrm{O}_{5}$. On the basis of this spectroscopic evidences and data reported in the literature (Khalid et al., 1988) compound 3 was identified as naringenin (Figure 2).

\subsubsection{Compound $4((+)$ catechin)}

Compound $4(97 \mathrm{mg})$ was obtained as light yellow- coloured powder. $\mathrm{R}_{\mathrm{f}}$ value of 0.23 on solvent system (1) and gave violet colour after spraying with $\mathrm{FeCl}_{3}$ reagent. The ${ }^{1} \mathrm{HNMR}$ spectrum $\left(400 \mathrm{MHz}, \mathrm{C}_{2} \mathrm{D}_{6} \mathrm{O}\right)$ displayed aromatic reasonances of three protons in an AMX system centered at $\delta 6.83\left(\mathrm{~d}, \mathrm{~J}=2 \mathrm{~Hz}, \mathrm{H}-2^{\prime}\right), 6.76(\mathrm{~d}, \mathrm{~J}=8 \mathrm{~Hz}$, $\left.\mathrm{H}-5^{\prime}\right)$ and $6.71\left(\mathrm{dd}, \mathrm{J}=2\right.$ and $\left.8 \mathrm{~Hz}, \mathrm{H}-6^{\prime}\right)$ and in association with other meta-coupled pair of doublets at $\delta 5.85(\mathrm{~d}$, $\mathrm{J}=2 \mathrm{~Hz}, \mathrm{H}-6)$ and $5.39(\mathrm{~d}, \mathrm{~J}=2 \mathrm{~Hz}, \mathrm{H}-8)$. Four protons signals in the aliphatic region in the form of an ABXY system at $\delta 4.59(\mathrm{~d}, \mathrm{~J}=8 \mathrm{~Hz}, \mathrm{H}-2), 3.97(\mathrm{~m}, \mathrm{H}-3), 2.50$ (dd, $\mathrm{J}=8$ and $\left.16 \mathrm{~Hz}, \mathrm{H}-4^{\prime}\right)$ and 2.84 (dd, J= 5 and $16 \mathrm{~Hz}$, $\left.\mathrm{H}-4^{\prime}\right)$. An ion peak at $\mathrm{m} / z 289.0718[\mathrm{M}-\mathrm{H}]^{-}$indicated that the molecular mass was 290 corresponding to the formula $\mathrm{C}_{15} \mathrm{H}_{14} \mathrm{O}_{6}$. On the basis of this spectroscopic evidences and data reported in the literature (Khalid et al., 1988) compound 4 identified $(+)$ catechin (Figure 2).

Comparison of the EtOAc extracts of the studied Acacia flowers using the isolated compounds as markers in TLC suggests the presence of gallic acid and its methyl ester in A. ehrenbergiana, A. nilotica ssp nilotica, A. seyal, A. sieberana, and $A$. tortilis. The two later species showed small quantity of gallic acid methyl ester by revealing faint violet-coloured spots, while the rest of the studied Acacia did not seem to contain these two compounds. Also catechin and naringenin were only detected in the two subspecies of $A$. nilotica.

\subsection{Palynological Study}

The microscopical examination of the pollen of the studied Acacia species showed that, 8 polyads were found in each anther with 4 polyads in each chamber. With the exception of $A$. laeta the polyads consisted of 16 monads with 8 monads centrally placed forming a sort of cubical block in which the individuals tended to be arranged in a rectangular fashion. The central group was surrounded by eight peripheral monads. According to the observed pollen characters two types of pollen were obtained, Type I pollen showed polyads with 78-102 $\mu$ in diameter and broken exine outline, included A. ehrenbergiana, A. nilotica, A. seyal, A. sieberana and A. tortilis (Figure 3-a) 
whereas Type II pollen displayed polyads with $46-97 \mu$ in diameter and continuous exine, included A. mellifera and A. senegal (Figure 3-b). A. laeta had polyad of 16 monads as well as 18-20 monads which were irregular and distorted (Figure 3-c).
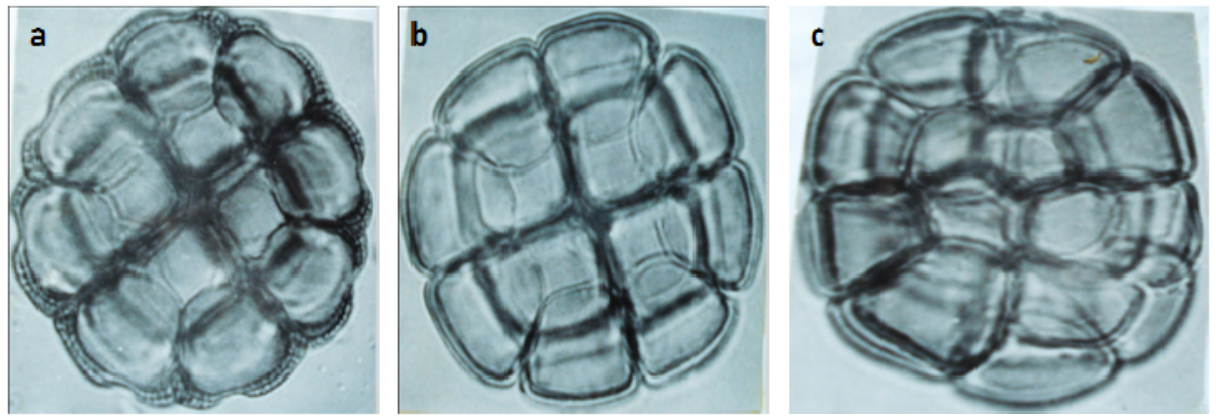

Figure 3. Pollen of Acacia species; a: Polyad of A. seyal representing Type I pollen; b: Polyad of A. senegal representing Type II pollen; c: Polyad of $A$. laeta with 18 monads supporting its hybrid origin

\section{Discussion}

According to the TLC chromatographic patterns the studied species can be classified into three major groups:

Group I: includes species reacted positively to $\mathrm{FeCl}_{3}$ reagent, with major violet-coloured spots. This group includes; A. ehrenbergiana, A. nilotica and A. seyal.

Group II: includes species reacted positively to $\mathrm{AlCl}_{3}$ reagent with major yellow-coloured spots. This group includes; A. mellifera, A.laeta and A. senegal.

Group III: includes species exhibiting positive reactivity towards both $\mathrm{FeCl}_{3}$ and $\mathrm{AlCl}_{3}$ reagents revealing spots with violet and yellow coloures respectively. This group includes; $A$. sieberana and A. tortilis.

The comparison of the species from the third group with Groups I and II showed that, they displayed the same major two violet-coloured spots as those of Group I but the colour intensity of one of them was lower in this Group. Moreover although they had the same degree of reactivity towards $\mathrm{AlCl}_{3}$ as those from Group II, they differed considerably in the spots polarity (Figure 1).

TLC comparison of the isolated compounds with the flowers EtOAc extracts of the studied Acacia species suggested that gallic acid and its methyl ester were persistent in A. ehrenbergiana, A. nilotica, A. seyal, A. sieberana, and $A$. tortilis indicative of their strong chemical affinity. However, A. sieberana, and A. tortilis were quite distinct from the others by their low concentration in gallic acid methyl ester as well as the presence of fluorescence spots that gave positive reaction with $\mathrm{AlCl}_{3}$ reagent. Morphologically these two species were characterized by creamy-coloured flowers, while the rest of species were with orange-coloured flowers. Palynology all the above mentioned species had polyad of 16 monads and broken exine outline which is in accordance with the work of Guinet (1990).

A. laeta, A. mellifera and A. senegal were characterized by displaying fluorescent and $\mathrm{AlCl}_{3}$ reactive spots. The chromatographical data showed that $A$. laeta exhibited stronger affinity towards A. mellifera. Palynologically, they all with the exception of $A$. laeta, had smaller size 16-celled polyads and continuous exine outline. A. laeta was different in having polyads both with the normal 16 monads and with 18-20 monads, which were slightly irregular and distorted. These characters supported the possibility of its hybrid origin from A. mellifera and A. senegale (Jackson \& Peake, 1955; Brenan, 1955). Elamin (1972) suggested that the closer affinity of $A$ laeta to $A$. mellifera was probably due to back crossing with it in the past. The results obtained in the present study were generally supportive to Elamin's classification. The relationships of the studied Acacia species are summarized in Table 1. 
Table 1. Relationship of some morphological, palynological and phytochemical characters of the studied Acacia species

\begin{tabular}{|c|c|c|c|c|c|c|c|c|}
\hline \multirow[t]{2}{*}{ Species } & \multirow{2}{*}{$\begin{array}{c}\text { Inflorescence } \\
\text { type }\end{array}$} & \multicolumn{2}{|c|}{ Vegetative character } & \multicolumn{2}{|c|}{ Palynological character } & \multicolumn{2}{|c|}{ TLC behaviour } & \multirow{2}{*}{$\begin{array}{c}\text { Elamin's } \\
\text { proposed } \\
\text { group }\end{array}$} \\
\hline & & Stipule nature & Armeture & Monad/polyad & Exine outline & Reagent & $\begin{array}{c}\text { Colour } \\
\text { developped }\end{array}$ & \\
\hline A. ehrenbergiana & Capitate & Spinescent & Spine & 16 & Broken & $\mathrm{FeCl}_{3}$ & Violet & I \\
\hline $\begin{array}{c}\text { A. nilotica } \mathrm{ssp} \\
\text { nilotica }\end{array}$ & Capitate & Spinescent & Spine & 16 & Broken & $\mathrm{FeCl}_{3}$ & Violet & I \\
\hline $\begin{array}{c}\text { A. nilotica } \mathrm{ssp} \\
\text { tomentosa }\end{array}$ & Capitate & Spinescent & Spine & 16 & Broken & $\mathrm{FeCl}_{3}$ & Violet & I \\
\hline A. seyal & Capitate & Spinescent & Spine & 16 & Broken & $\mathrm{FeCl}_{3}$ & Violet & 1 \\
\hline A. sieberana & Capitate & Spinescent & Spine & 16 & Broken & $\mathrm{AlCl}_{3} \& \mathrm{FeCl}_{3}$ & $\begin{array}{c}\text { Yellow \& } \\
\text { violet }\end{array}$ & I \\
\hline A. tortilis & Capitate & Spinescent & Spine & 16 & Broken & $\mathrm{AlCl}_{3} \& \mathrm{FeCl}_{3}$ & $\begin{array}{c}\text { Yellow \& } \\
\text { violet }\end{array}$ & 1 \\
\hline A. mellifera & Spicate & Nonspinescent & Prickles & 16 & Continuous & $\mathrm{AlCl}_{3}$ & Yellow & II \\
\hline A. laeta & Spicate & Nonspinescent & Prickles & 16 and $16-20$ & Continuous & $\mathrm{AlCl}_{3}$ & Yellow & II \\
\hline A. senegal & Spicate & Nonspinescent & Prickles & 16 & Continuous & $\mathrm{AlCl}_{3}$ & Yellow & II \\
\hline
\end{tabular}

In conclusion, the data obtained from both phytochemical and palynological studies were useful for taxonomic purposes in the Sudan Acacia. The preliminary phytochemical screening and isolation of some phenolic compounds pointed out the necessity of characterization of phenolic compounds present in all Sudan Acacia in order to obtain a better insight of the pattern of their occurrence in different taxonomical groups, as well as to evaluate their potentiality as chemotaxonomical markers.

\section{References}

Andrews, F. W. (1952). The flowering plants of the An glo-Egyptian Sudan, Vol. 1, Buncle \& Co. Ltd., Arbroath, Scotland.

Bentham, G. (1842). Notes on Mimoseae, with a synopsis of species. Tribe II. London Journal of Botany, 1, 318-392, 494-528.

Bentham, G. (1862). Acacia. In: Flora Australiensis. 2. L. Reeve and Co, London, pp. 301-421.

Bentham, G. (1875). Revision of the suborder Mimoseae. Transactions of the Linnean Society of London, 1, 335-664. http://dx.doi.org/10.1111/j.1096-3642.1875.tb00005.x

Bouchenak-Khelladi, Y., Maurin, O., Hurter, J., \& van der Bank, M. (2010). The evolutionary history and biogeography of Mimosoideae (Leguminosae): An emphasis on African acacias. Molecular Phylogenetics and Evolution, 57, 495-508. http://dx.doi:10.1016/j.ympev.2010.07.019

Brenan, J. P. M. (1955). Notes on Mimosoideae: I. Kew Bulletin, 10, 161-192. http://dx.doi.org/10.2307/4108864

Brown, A. F., \& Massey, R. E. (1929). Flora of the Sudan. Thomas Murby and Co., London: UK.

Crowfoot, G. M. (1929). Flowering plants of the northern and central Sudan. Orphans Printing Press Ltd., Leominster: UK.

Dube, J. S., Reed, J. D., \& Ndlovu, L. R. (2001). Proanthocyanidins and other phenolics in Acacia leaves of Southern Africa. Animal Feed Science and Technology, 91, 59-67. http://dx.doi.org/10.1016/S0377-8401(01)00229-2

Elamin, H. M. (1972). Taxonomic studies on Sudan Acacias. MSc thesis, Edinburgh University: UK.

El Tinay, A. H., Karamalla, K. A., El amin, H. M., Shigidi, M. T. A., \& Ishag, K. E. A. (1979). Serotaxonomic Studies on Sudan Acacias. Journal of Experimental Botany, 30(3), 607-615.

Erdman, G. (1969). Handbook of palynology. An introduction of the study of pollen grains and spores. Brill, Leiden, Copenhagen.

Evans, C. S., Qureshi, Y. M., \& Bell, E. A. (1977). Free amino acids in the seeds of Acacia species. Phytochemistry, 16, 565-570. http://dx.doi.org/10.1016/0031-9422(77)80016-2 
Evans, C. S., Shah, A. J., Adlard, M. W., \& Rico, A. M. L. (1993). Non-protein amino acids in seeds of $\begin{array}{llll}\text { neotropical species } \quad \text { of } & \text { Acacia. } & \text { Phytochemistry, } & 32,126 .\end{array}$ http://dx.doi.org/10.1016/0031-9422(92)80116-V

Guinet, P., \& Vassal, J. (1978). Hypothesis on the differentiation of the major groups in the genus Acacia (Leguminosae). Kew Bulletin, 32, 509-527.

Guinet, P. (1990). The genus Acacia (Leguminosae, Mimosoideae): its affinities as borne out by its pollen characters. Plant systematics and evolution Suppl, 5, 81-90. http://dx.doi.org/10.1007/978-3-7091-9079-1_7

Harison, N., \& Jackson, J. K. (1958). Ecological classification of vegetation of Sudan. Forest Bulletin, 2, 1-45. Khartoum.

Jackson, J. K., \& Peake, F. G. G. (1955). Forestry research in the Sudan: 1950-1954, (No. 7). Agricultural Publications Committee in Khartoum.

Khalid, S. A., Yagi, S. M., Khristova, P., \& Duddeck, H. (1988). (+) Catechin-5-galloyl ester as novel natural polyphenol from the bark of Acacia nilotica of Sudanese origin. Planta medica, 55, 556-558. http://dx.doi.org/10.1055/s-2006-962094

Mabberley, D. J. (1997). The plant book: a portable dictionary of vascular plants (2nd ed.). Cambridge University Press.

Maslin, B. R. (2001). Introduction to Acacia. In A. E. Orchad, \& Wilson, A. J. G. (Eds.), Flora of Australia. Melbourne: CSIRO Publishing.

Pedley, L. (1986). Derivations and dispersal of Acacia (Leguminosae) with particular reference of Australia, and the recognition of Senegalia and Racosperma. Botanical Journal of the Linnean Society, 92, 219-254. http://dx.doi.org/10.1111/j.1095-8339.1986.tb01429.x

Quinlan, J. R. (1993). Programs for Machine Learning, San Mateo, CA: Morgan Kaufmann, USA.

Stuessy, T. F. (2009). Plant taxonomy: The systematic evaluation of comparative data. (2nd ed.). New York : Columbia University Press.

Vassal, J. (1972). Apport des recherches ontogénique et séminologiques à l'étude morphologique, taxonomique et phylogénique du genre Acacia. Bulletin de la Socit d'histoire naturelle de Toulouse, 108, 105-247.

Vassal, J. (1981). Acacieae. In R. M. Polhill, \& P. H. Raven (eds.). Advances in Legume Systematics (Part 1, pp. 169-172). Royal Botanic Gardens, Kew, London, UK. 